\title{
Comparing Chemical Coagulation and Electrocoagulation on removal efficiency of Chromium (VI) from Galvanic Effluents
}

\author{
Konstantinos Dermentzis", Kokkoni Karakosta, Christina Chatzichristou and Thomas Spanos \\ Department of Chemistry, School of Science, International Hellenic University, 65404 Agios Loucas, Kavala, Greece \\ Hephaestus Advanced Research Laboratory, School of Science,International Hellenic University, 65404 Agios Loucas, Kavala, Greece
}

Received 12 January 2021; Accepted 7 May 2021

\begin{abstract}
Hexavalent chromium is a very toxic heavy metal moiety occurring in various industrial wastewaters, such as electroplating, anodizing, tanning dyeing effluents. Industrial effluents may contain hundreds $\mathrm{mg} / \mathrm{L}$ of $\mathrm{Cr}(\mathrm{VI})$, whereas the upper allowed limit for effluent discharge to aquatic systems is $0.5 \mathrm{mg} / \mathrm{L}$. In the present study, the removal of chromium from real electroplating effluents is presented using the chemical coagulation with addition of iron sulfate coagulant and the electrocoagulation process with iron electrodes. The optimal affecting parameters for the chemical coagulation process were found to be solution $\mathrm{pH} 11$ and coagulant dose $500 \mathrm{mg} / \mathrm{L}$, whereas for electrocoagulation $\mathrm{pH} 11$ and applied current density $15 \mathrm{~mA} / \mathrm{cm} 2$. Both processes achieved a rapid and effective chromium removal of over $99.9 \%$ with the electrochemical process being superior in terms of total operational costs.
\end{abstract}

Keywords: chemical coagulation; electrocoagulation; hexavalent chromium; ferrous sulfate; iron electrodes.

\section{Introduction}

Contamination of the environment with chromium originates from various industrial activities, such as metallurgical, anodizing, dyeing, tanning and dyeing plants. The oxidation state of the metal determines its toxicity. Hexavalent chromium is 100 times more toxic than trivalent. Industrial effluents usually contain 10 to $500 \mathrm{mg} / \mathrm{L} \mathrm{Cr}$ (VI) that according to international environmental rules must be set at permissible levels before being discharged into the environment. The upper permitted levels of chromium are 0.5 $\mathrm{mg} / \mathrm{L}$ for effluent discharge and $0.01 \mathrm{mg} / \mathrm{L}$ for drinking water respectively.

Various treatment methods for chromium removal have been proposed, such as chemical precipitation-coagulationflocculation [1-3], adsorption [4[, ion exchange [5] and electrochemical methods: electrodialysis-electrodeionization [6] and electrocoagulation [7-10]. Martin-Dominguez et al. [1] treated aquifer water with an initial total chromium concentration of $19.0 \mathrm{mg} / \mathrm{L}$ using iron as coagulation agent, followed by flocculation, sedimentation and sand-filtration steps and achieved more than $99 \%$ removal of $\mathrm{Cr}$ and a residual concentration of $<0.05 \mathrm{mg} / \mathrm{L}$. Qin et al. [2] tested for removal of $\mathrm{Cr}(\mathrm{VI})$ from contaminated groundwater in a flowthrough pilot-scale system by reduction of $\mathrm{Cr}(\mathrm{VI})$ to $\mathrm{Cr}(111)$ with ferrous sulfate followed by coagulation and filtration leading to reduction of the influent $\mathrm{Cr}(\mathrm{VI})$ concentrations of $100 \mu \mathrm{g} / \mathrm{L}$ to very low concentrations $<5 \mu \mathrm{g} / \mathrm{L}$. Complete reduction of $\mathrm{Cr}(\mathrm{VI})$ to $\mathrm{Cr}(111)$ was accomplished with $\mathrm{Fe}(11)$ doses of 10-50 times the $\mathrm{Cr}(\mathrm{Vl})$ concentration. Stylianou et al. [3] investigated the reduction of $\mathrm{Cr}(\mathrm{VI})$ in pipe flocculation reactors using a molar ratio $\mathrm{Fe}(\mathrm{II}) / \mathrm{Cr}(\mathrm{VI})$ of around 3 leading to a reduction of $\mathrm{Cr}(\mathrm{VI})$ below $10 \mu \mathrm{g} / \mathrm{L}$ from an initial concentration of $300 \mu \mathrm{g} / \mathrm{L}$.

*E-mail address: koderm@chem.ihu.gr

ISSN: 1791-2377 @ 2021 School of Science, IHU. All rights reserved.

doi:10.25103/jestr.142.07
Altun et al. [4] investigated he removal of $\mathrm{Cr}(\mathrm{VI})$ ions from aqueous solutions by adsorption on bio-chars produced by the pyrolysis of walnut shells at $450{ }^{\circ} \mathrm{C}(\mathrm{BC} 450)$ and the co-pyrolysis of walnut shells and $20 \mathrm{wt} \%$ tar sand (BCTS20) at the same temperature, where the $\mathrm{Cr}(\mathrm{VI})$ removal percentages under optimal conditions were 80.47 and $95.69 \%$ for BC450 and BCTS20, respectively. Meshram et al. [5] tested to removal of $\mathrm{Cr}(\mathrm{VI})$ from a model as well as from the untreated chromite mine effluent samples using the strong basic anion exchange resins, Amberlite IRA 400 and IRA 900. For an initial concentration of $50 \mathrm{ppm} \mathrm{Cr}$ (VI), IRA 400 was found to adsorb $\mathrm{Cr}(\mathrm{VI})$ completely in less than 6 min of contact time and was efficient in a larger range of $\mathrm{pH}(1-6)$, whereas IRA 900 was able to remediate $97 \% \mathrm{Cr}(\mathrm{VI})$ in the $\mathrm{pH}$ range 4.5-5 in less than $10 \mathrm{~min}$.

Dharnaik \& Ghosh [6] used a laboratory-scale plate and frame-type electrochemical ion-exchange cell for removal of hexavalent chromium from synthetic wastewater containing $5 \mathrm{mg} / \mathrm{l} \mathrm{Cr}$ (VI) under varying applied voltages. Up to $99 \%$ of chromium removal was noticed in the electrodeionization cell containing fresh resin at applied voltages of $10 \mathrm{~V}$ and higher. Akbal \& Camci [7] tested the removal of heavy metals, $\mathrm{Cu}$, $\mathrm{Cr}$, Ni from metal plating wastewater by electrocoagulation and chemical coagulation. Chemical coagulation was performed using both, aluminum sulfate or ferric chloride, whereas electrocoagulation was done in an electrolytic cell using aluminum and iron electrodes. By chemical coagulation, $\mathrm{Cu}-, \mathrm{Cr}-$, and Ni-removal of $99.9 \%$ was achieved with aluminum sulfate and ferric chloride dosages of 500, 1000, and $2000 \mathrm{mg} \mathrm{L}^{-1}$, respectively. Electrocoagulation with iron electrodes at a current density of $10 \mathrm{~mA} \mathrm{~cm}^{-2}$, electroprocessing time of $20 \mathrm{~min}$, and $\mathrm{pH} 3.0$ resulted in $99.9 \% \mathrm{Cu}-, 99.9 \% \mathrm{Cr}-$, and $98 \% \mathrm{Ni}$-removal.

In our previous work [8] we investigated the removal of hexavalent chromium from synthetic aqueous solutions and actual industrial electroplating wastewater with initial chromium concentrations of $200-800 \mathrm{mg} / \mathrm{L}$ by 
electrocoagulation with iron electrodes. Results revealed that best removal percentage was achieved at a current density 40 $\mathrm{mA} / \mathrm{cm}$ in 50 minutes of electroprocessing time. In our other previous work [9] we proposed an electrocoagulation process powered by photovoltaic solar energy which was capable of reducing the initial $\mathrm{Cr}(\mathrm{VI})$ concentration from the initial value of $96 \mathrm{mg} / \mathrm{L}$ to less than the permissible limit and achieving a removal percentage of over 99\%. El-Taweel et al. [10] experimented electrocoagulation with a new anode design consisting of hex nuts connected with a thin rode of iron and found as optimum conditions for hexavalent chromium removal, $100 \mathrm{mg}$ of $\mathrm{Cr}(\mathrm{VI}) / 1,0.55 \mathrm{~A}, 1.5 \mathrm{~g}$ of sodium chloride and $\mathrm{pH} 1$.

Chemical coagulation is a phenomenon where the dispersed charged colloidal particles of pollutants are neutralized by the highly and oppositely charged coagulant particles resulting in the formation of larger agglomerates and their final precipitation. Coagulation-flocculation is based on the reduction of the particles net surface charge and the elimination of their electric double-layer, which is caused by the addition of the well known coagulants, such as $\mathrm{FeCl}_{3}$, $\mathrm{Al}_{2}(\mathrm{SO} 4)_{3}$ or organic polyelectrolytes.

A new alternative way to conventional chemical coagulation is the electrochemical coagulation or electrocoagulation, in which the coagulants $\mathrm{Fe}(\mathrm{OH})_{3}$ and $\mathrm{Al}(\mathrm{OH})_{3}$ are not added to the treated solution but are generated locally by electrodissolution of a corrodible anode made of iron or aluminum.

When iron anodes are used, the anodically produced $\mathrm{Fe}^{2+}$ and $\mathrm{Fe}^{3+}$ ions are combined with the cathodically produced $\mathrm{OH}^{-}$ions forming the coagulants $\mathrm{Fe}(\mathrm{OH})_{2}$ and $\mathrm{Fe}(\mathrm{OH})_{3}$ according to reactions (1) and (2):

$\mathrm{Fe}^{2+}+2 \mathrm{OH}^{-} \rightarrow \mathrm{Fe}(\mathrm{OH})_{2}$
$\mathrm{Fe}^{3+}+3 \mathrm{OH}^{-} \rightarrow \mathrm{Fe}(\mathrm{OH})_{3}$

During the electrocoagulation process the hexavalent $\mathrm{Cr}(\mathrm{VI})$ ions are reduced to trivalent $\mathrm{Cr}$ (III) ions in two ways: a) chemically by reduction with the $\mathrm{Fe}^{2+}$ ions and b) electrochemically by reduction at the cathode according to reactions (3) and (4) respectively:

$$
\begin{aligned}
& \mathrm{Cr}_{2} \mathrm{O}_{7}^{2-}+6 \mathrm{Fe}^{2+}+14 \mathrm{H}^{+} \rightarrow 2 \mathrm{Cr}^{3+}+6 \mathrm{Fe}^{3+}+7 \mathrm{H}_{2} \mathrm{O} \\
& \mathrm{Cr}_{2} \mathrm{O}_{7}^{2-}+6 \mathrm{e}+14 \mathrm{H}^{+} \rightarrow 2 \mathrm{Cr}^{3+}+7 \mathrm{H}_{2} \mathrm{O}
\end{aligned}
$$

The generated $\mathrm{Cr}^{3+}$ ions react with the generated $\mathrm{OH}^{-}$ions forming the insoluble precipitate $\mathrm{Cr}(\mathrm{OH})_{3}$ according to reaction (5):

$\mathrm{Cr}^{3+}+3 \mathrm{OH}^{-} \rightarrow \mathrm{Cr}(\mathrm{OH})_{3}$

As far as we are aware, only few studies appear in literature combining the chemical and electrochemical coagulation and comparing their effectiveness in reducing the chromium concentration from wastewaters. In the present work, the removal of toxic $\mathrm{Cr}(\mathrm{VI})$ ions from real aqueous chromium wastes is studied by both, the conventional chemical coagulation and electrocoagulation. The parameters influencing the effectiveness of the two methods, such as $\mathrm{pH}$, coagulant dose, chromium concentration, current density, and electrolysis time, are investigated and determined. The two methods are compared and evaluated.

\section{Methodology}

\subsection{Reagents}

All reagents, $\mathrm{FeCl}_{3} \cdot 6 \mathrm{H}_{2} \mathrm{O}, \mathrm{NaOH}, \mathrm{HCl}, \mathrm{NaCl}$ are of purity grade (Merck). The $\mathrm{pH}$ of the wastewater is adjusted by addition of appropriate amounts of $0.1 \mathrm{NaOH}$ and $0.1 \mathrm{M} \mathrm{HCl}$ solutions. The real wastewater sample was received from an electroplating unit located in Northern Greece. Its main characteristics are listed in Table 1.

Table 1. Main characteristics of treated real electroplating wastewater sample.

\begin{tabular}{l|c}
\hline $\mathrm{pH}$ & 4.1 \\
\hline Conductivity $(\mu \mathrm{S} / \mathrm{cm})$ & 1524.0 \\
\hline $\mathrm{Cr}(\mathrm{VI})(\mathrm{mg} / \mathrm{L})$ & 300.0 \\
\hline
\end{tabular}

\subsection{Chemical coagulation process}

Chemical coagulation experiments were carried out using the jar testing technique. The ferric chloride coagulant solution was prepared by dissolving a similar amount of $\mathrm{FeCl}_{3} \cdot 6 \mathrm{H}_{2} \mathrm{O}$ in deionized water $(30 \mathrm{~g} / \mathrm{L})$. The calculated volume of the coagulant solution is added to $200 \mathrm{ml}$ of wastewater under rapid stirring at $200 \mathrm{rpm}$ for 5 minutes. Then a slower stirring at $60 \mathrm{rpm}$ was followed for another 25 minutes. Afterwards, the reaction mixture was allowed to stand for 60 minutes and finally was filtered out with polytrifluoroethylene filter paper (Whatman $0.45 \mu \mathrm{m}$ ) and the chromium concentration was determined in the filtrate.

\subsection{Electrocoagulation procedure}

The electrocoagulation experiments were carried out in a 500 $\mathrm{mL}$ cylindrical electrochemical cell with a volume of $200 \mathrm{~m}$ of treated wastewater and stirring at $200 \mathrm{rpm}$. Three iron plates in parallel (one central cathode and two outer anodes) were used as electrodes, immersed to $5 \mathrm{~cm}$ in the treated solution with dimensions of $5 \times 5 \times 0.3 \mathrm{~cm}$, a surface area of $25 \mathrm{~cm}$ and a distance of $1 \mathrm{~cm}$ between them. Every 10 minutes of electrolysis time, $2 \mathrm{ml}$ samples are taken from the treated solution, filtered through filter paper (Whatman $0.45 \mu \mathrm{m}$ ) and carried for analysis.

\subsection{Instruments}

The DC power supply Agilent (E3612A, USA) served to provide constant measurements of current and voltage. Conductivity measurements were made with the conductometer (inoLab). The solution $\mathrm{pH}$ and temperature were measured with the $\mathrm{pH}$-meter (Hana HI8314) comprising a temperature sensor. Atomic Absorption Spectroscopy (Perkin Elmer 5100) was used for determination of the chromium concentration.

\section{Results and Discussion}

\subsection{Chromium removal by chemical coagulation}

\subsubsection{Influence of $\mathrm{pH}$ on chemical coagulation}

The solution $\mathrm{pH}$ is one of the most important parameters that determine the effectiveness of the chemical coagulation process. To find the optimum $\mathrm{pH}$ value the chemical coagulation treatment was tested with initial $\mathrm{pH}$ values ranging from 3 to 11 . Wastewater samples of same parameters of volume, initial chromium concentration, coagulant dose, operation time and different initial $\mathrm{pH}$ values were placed in the jar testing apparatus and after the coagulation performance the chromium concentration was analyzed. Figure 1 illustrates the effect of $\mathrm{pH}$ on chromium removal 
during the chemical coagulation of the wastewater with the $\mathrm{FeCl}_{3}$ coagulant.

Chromium removal is increased by increasing $\mathrm{pH}$, giving optimum removal efficiency at alkaline $\mathrm{pH}=11$. For $\mathrm{pH}$ values 3 to 11 and $400 \mathrm{mg} / \mathrm{L}$ coagulant concentration, chromium removal efficiency ranges from 34.6 to $89.6 \%$, respectively.

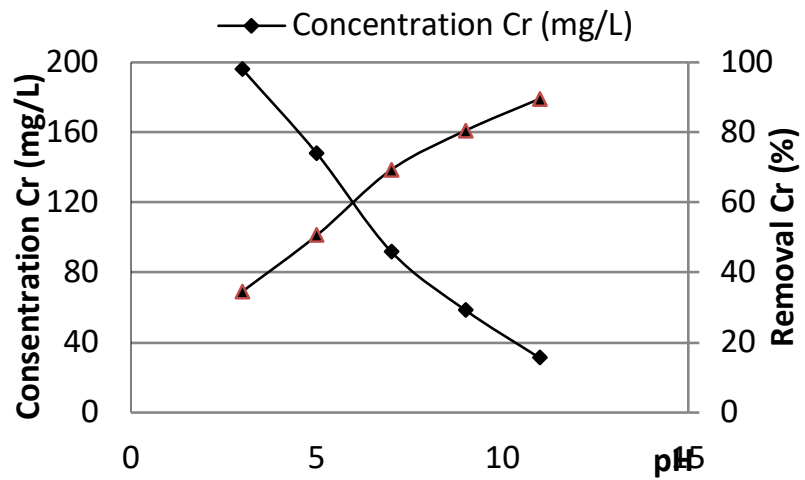

Fig. 1. Residual chromium concentration and removal percentage versus solution $\mathrm{pH}$ during chemical coagulation.

\subsubsection{Effect of coagulant concentration on chemical coagulation}

To find the optimum coagulant concentration, the wastewater samples were treated with various coagulant concentrations ranging from 100 to $600 \mathrm{mg} / \mathrm{L}$, while keeping constant all other parameters, such as the investigated optimum initial $\mathrm{pH} 11$, volume, initial chromium concentration and operation time. Figure 2 illustrates the effect of the concentration of the added ferric chloride coagulant on chemical coagulation to remove chromium from the treated electroplating wastewater.

The removal efficiency of chromium increases with increasing dose of coagulant. The percent removal efficiency of chromium is $34.9,72.8$ and $89.6 \%$ for 100,200 and 400 $\mathrm{mg} / \mathrm{L}$ coagulant doses, respectively. Almost complete removal of chromium by $99.9 \%$ is achieved at coagulant doses of $500 \mathrm{mg} / \mathrm{L}$ or more. Our findings are in good agreement with the findings of Akbal \& Camci [7].



Fig. 2. Residual chromium concentration and removal percentage versus coagulant concentration during chemical coagulation.

\subsection{Chromium removal by electrocoagulation}

3.2.1 Influence of $\mathrm{pH}$ on electrocoagulation

As is known, the initial solution $\mathrm{pH}$ is crucial for the efficiency of electrocoagulation. For initial $\mathrm{pH}$ values $<7$, the observed increase in $\mathrm{pH}$ is due to the release of hydrogen and the formation of $\mathrm{OH}^{-}$ions at the cathode. In an alkaline environment $(\mathrm{pH}>8)$ the final $\mathrm{pH}$ does not change markedly since the $\mathrm{OH}^{-}$anions generated at the cathode combine with the generated $\mathrm{Fe}^{2+}$ and $\mathrm{Fe}^{3+}$ cations forming the corresponding necessary coagulant species $\mathrm{Fe}(\mathrm{OH})_{2}$ and $\mathrm{Fe}(\mathrm{OH})_{3}$ according to the reactions (3) and (4).

In addition, $\mathrm{OH}^{-}$ions are coupled to the produced $\mathrm{Cr}^{3+}$ ions forming the insoluble $\mathrm{Cr}(\mathrm{OH})_{3}$ according to reaction (5). To demonstrate the influence of the initial $\mathrm{pH}$ on the electrocoagulation performance, experiments were carried out using a wastewater sample containing $300 \mathrm{mg} / \mathrm{L} \mathrm{Cr}(\mathrm{VI})$ in the $\mathrm{pH}$ range 3-11. As shown in Figure 3, after a $20 \mathrm{~min}$ long electroprocessing time at the constant current density of $10 \mathrm{~mA} / \mathrm{cm}^{2}$, the removal of $\mathrm{Cr}(\mathrm{VI})$ increased significantly with increasing $\mathrm{pH}$ throughout the $\mathrm{pH}$ range of 3-11. In our previous works $[8,9]$ we investigated that in the acidic environment $(\mathrm{pH}<3)$ the removal of $\mathrm{Cr}(\mathrm{VI})$ is significantly reduced due to a decrease in the oxidation state of $\mathrm{Fe}^{3+}$ to $\mathrm{Fe}^{2+}$. It is well known that $\mathrm{Fe}^{3+}$ ions favor the coagulation/flocculation process much more than $\mathrm{Fe}^{2+}$ ions. Sharma et al., 2020 [11] reported that the slightly alkaline $\mathrm{pH}$ 9.5 was the best for removal of chromium (91.7\%) and lead $(91.3 \%)$ from electroplating effluents by electrocoagulation with iron electrodes.

Based on our experimental results, as illustrated in Figure 3 , the electrochemical coagulation process showed at $\mathrm{pH} 11$ a superior and almost complete removal of $\mathrm{Cr}(\mathrm{VI})$ ions $(>99.9$ $\%)$ compared to conventional chemical coagulation (89.6\%). This can be explained by the contribution of reactions (3), (4) and (5) to further significant reduction of $\mathrm{Cr}(\mathrm{VI})$ to $\mathrm{Cr}(\mathrm{III})$ ions and additional elimination of chromium by precipitation as insoluble $\mathrm{Cr}(\mathrm{OH})_{3}$.

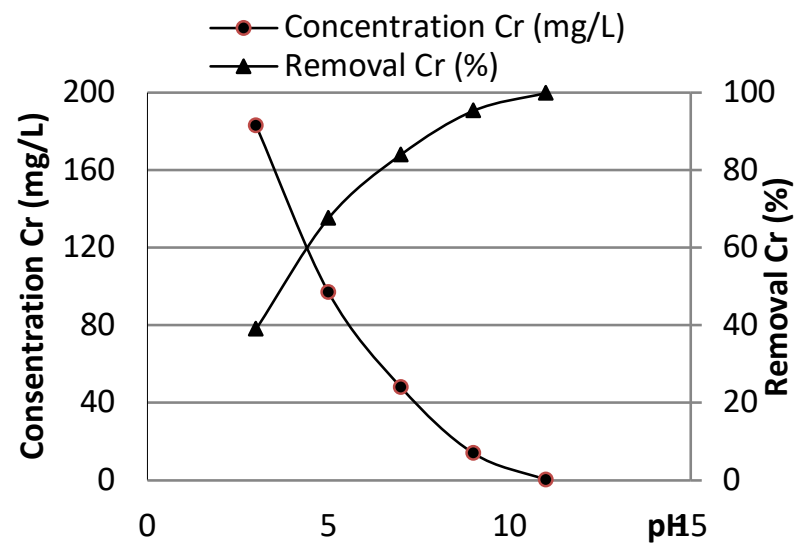

Fig. 3. Residual chromium concentration and removal percentage versus solution $\mathrm{pH}$ during electrocoagulation.

\subsubsection{Influence of current density on electrocoagulation}

As well known, the applied current density defines the dosage rate and particle size of the electrochemically generated coagulating agent and additionally also the rate of the hydrogen bubble production leading to a faster removal of pollutants. Koshla et al. [12] studied the large number of factors, such as electrode material, electrode surface/morphological properties, $\mathrm{pH}$ and current density affecting the size distribution of the gas bubble, which are generated by electrolysis and their importance on electroflotation and electrocoagulation processes.

Measurements were conducted at the current densities of 5,10 and $15 \mathrm{~mA} / \mathrm{cm}^{2}$, with the initial $\mathrm{Cr}(\mathrm{VI})$ concentration of $300 \mathrm{mg} / \mathrm{L}$ and the initial actual wastewater $\mathrm{pH}=4.1$.

According to Figure 4, the chromium removal efficiency increases, as anticipated, with increasing applied current density. The hexavalent chromium ions, Cr(VI), were first 
reduced to trivalent $\mathrm{Cr}^{3+}$ ions according to reactions (3) and (4), which then were joined to the produced $\mathrm{OH}^{-}$ions and precipitated as insoluble $\mathrm{Cr}(\mathrm{OH})_{3}$ as stated with reaction (5) or were adsorbed in the particles of the coagulating agents $\mathrm{Fe}(\mathrm{OH})_{3}$ and $\mathrm{Fe}(\mathrm{OH})_{2}$.

For the applied current densities 5,10 and $15 \mathrm{~mA} / \mathrm{cm}^{2}$, the initial $\mathrm{Cr}(\mathrm{VI})$ concentration of $300 \mathrm{mg} / \mathrm{L}$ was reduced below the permissible limits $(0.5 \mathrm{mg} / \mathrm{L})$ in 35,20 , and 10 minutes, respectively. Similar findings of over $99 \%$ chromium (VI) removal by electrocoagulation with iron electrodes have been reported by other researchers. Akbal \& Camci [7] and Cheballah et al. [13] announced removal percentages of 99.9 and $100 \%$ respectively for hexavalent chromium with iron electrodes.

\subsection{Comparison of chemical coagulation and} electrocoagulation

The efficiencies of the two studied coagulation methods were compared on the basis of coagulant consumption, electricity consumption, electrode mass loss, the amount of sludge produced and the processing time required.

Sections 3.1.2 and 3.2.2 show that for the complete removal of chromium from the treated wastewater volume of $1 \mathrm{~m}^{3}$ with the initial $\mathrm{Cr}(\mathrm{VI})$ concentration of $300 \mathrm{mg} / \mathrm{L}$ during the chemical coagulation process $0.9 \mathrm{~kg}$ of coagulant $\mathrm{FeCl}_{3} \cdot 6 \mathrm{H}_{2} \mathrm{O}$ and 30 minutes processing time are required, whereas $0.66 \mathrm{Kg}$ of sludge is produced. The electrocoagulation process for the same wastewater volume of same chromium concentration requires $0.651 \mathrm{Kg}$ of iron anode, $0.36 \mathrm{kWh}$ of electricity whereas $1.23 \mathrm{Kg}$ of sludge is produced.

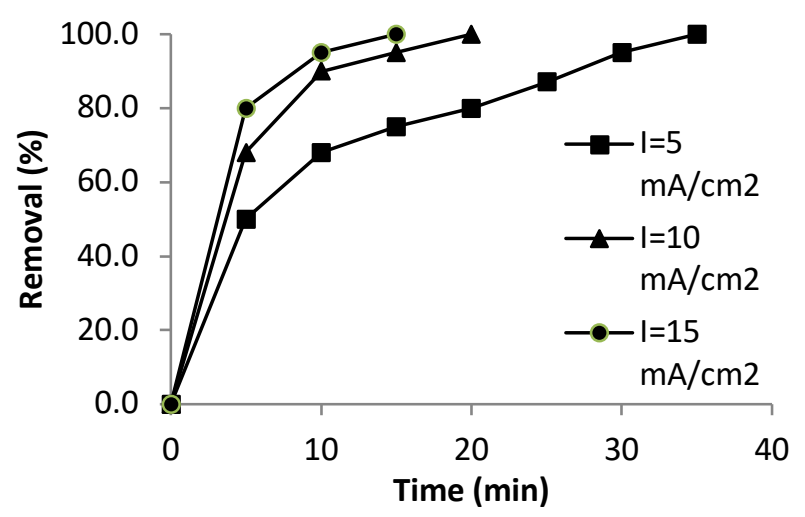

Fig. 4. Chromium removal percentage versus time at various current densities.

The total costs for chemical and electrochemical coagulation are estimated at $1.03 € / \mathrm{m}^{3}$ and $0.69 € / \mathrm{m}^{3}$ of treated wastewater respectively.

Both methods are therefore effective in removing hexavalent chromium from industrial electroplating effluents with the electrochemical process being advantageous over the chemical in terms of total costs.

Similar results of economic estimation have been reported also by other researchers. Akbal \& Camci [7] investigated the total costs of $0.859 \mathrm{US} \$ / \mathrm{m}^{3}$ for chemical coagulation and $0.590 \mathrm{US} \$ / \mathrm{m}^{3}$ for electrocoagulation respectively when treating electroplating effluents of $45 \mathrm{mg} / \mathrm{L} \mathrm{Cu}, 44.5 \mathrm{mg} / \mathrm{L} \mathrm{Cr}$ and $394 \mathrm{mg} / \mathrm{L} \mathrm{Ni}$. Aygun et al. [14] reported that the operating costs during the electrocoagulation treatment of dye house wastewater were approximately $2 \%$ for energy, $28 \%$ for electrode and $70 \%$ for chemical consumption.

Another aspect that should be taken into consideration is the fact that during the electrochemical treatment a considerable amount of electrolytic hydrogen gas is produced at the cathode due to electrochemical water splitting, which under suitable cell configuration could be collected and stored. The corresponding energy recovery through the produced hydrogen gas is given from next equation (1):

$\mathrm{E}_{H 2}=\mathrm{m}_{H 2} \times 122 \mathrm{~kJ} / \mathrm{g}_{H 2}$

where $\boldsymbol{m}$ is the mass of produced hydrogen and $122 \mathrm{~kJ}$ is the specific heat per $g$ of hydrogen.

The amount of produced hydrogen and, therefore, the corresponding associated energy recovery can be calculated from Faraday's law of electrolysis and can amount to about $10-25 \%$ of the needed electrical energy for conducting the electrochemical treatment. It depends mainly on the pollutant concentration of treated wastewater, the electrolysis time and the applied current density. In our previous work [15] we achieved, during the continuous electrocoagulation treatment of nickel phthalocyanine dye at the inlet flow rate $60 \mathrm{~mL} / \mathrm{min}$ and current density $10 \mathrm{~mA} / \mathrm{cm}^{2}$, about $175 \mathrm{~L}$ hydrogen gas per $\mathrm{m}^{3}$ of treated wastewater, which corresponds to $12.5 \%$ of energy recovery. Deghles \& Kurt [16] reported energy harvesting of 15 and $16 \%$ during electrocoagulation of tannery wastewater using iron and aluminum electrodes respectively.

Thus, the electrochemical coagulation process offers a double useful objective, namely wastewater remediation and energy recovery.

\section{Conclusion}

The present study investigated the treatment of actual electroplating wastewater for removal of hexavalent chromium by chemical and electrochemical coagulation. The chemical treatment of a wastewater containing an initial concentration $300 \mathrm{mg} / \mathrm{L} \mathrm{Cr}$ (VI) resulted in $99.9 \%$ effective removal of the metal at a coagulant dose of $500 \mathrm{mg} / \mathrm{L}$ $\mathrm{FeCl}_{3} \cdot 6 \mathrm{H}_{2} \mathrm{O}$ in 30 minutes.

The electrochemical treatment using iron electrodes achieved a rapid and effective $99.9 \%$ reduction of chromium with an applied current density of $10 \mathrm{~mA} / \mathrm{cm}^{2}$ and an electrolysis time of 20 minutes. Both methods of coagulation are effective for removing hexavalent chromium from industrial wastewaters, such as galvanic effluents. The electrochemical process has proved to be more advantageous over the chemical in terms of overall costs and effectiveness.

This is an Open Access article distributed under the terms of the Creative Commons Attribution License.

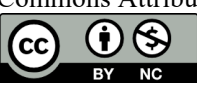

\section{References}

1. Martin-Dominguez A., Rivera-Huerta M.L., Perez-Castrejon S., Garrido-Hoyos S.E., Villegas-Mendoza I.E., Gelover-Santiago S.L., Drogui P., Buelna G., Chromium removal from drinking water by redox-assisted coagulation: chemical versus electrocoagulation, Sep. Purif. Technol. (2018) 200 266-272. 
Konstantinos Dermentzis, Kokkoni Karakosta, Christina Chatzichristou and Thomas Spanos/

Journal of Engineering Science and Technology Review 14 (2) (2021) 54 - 58

2. Qin G., McGuire M.J., Blute N.K., Seidel C., Fong L., Hexavalent chromium removal by reduction with ferrous sulfate, coagulation and filtration: A pilot-scale study, Environ. Sci. Technol. (2005) 39 6321-6327.

3. Stylianou S., Simeonidis K., Mitrakas M., Zouboulis A., Ernst M., Katsoyiannis I.A., Reductive precipitation and removal of $\mathrm{Cr}(\mathrm{VI})$ from ground waters by pipe flocculation-microfiltration, Environ. Sci. Pollut. Res. Int. 25 (2018) 12256-12262.

4. Altun T. Kar Y., Removal of $\mathrm{Cr}(\mathrm{VI})$ from solution by pyrolytic charcoals, New carbon Mater. 31 (2016) 501-509.

5. Meshram P., Ghosh A., Ramamurthy Y., Pandey B.P., Torem A.M.L., Removal of hexavalent chromium from mine effluents by ion exchange resins-comparative study of Amberlite IRA 400 and IRA 900.

6. Dharnaik A.S., Ghosh P.K., Hexavalent chromium [Cr(VI)] removal by the electrochemical ion-exchange process, 35 (2014) 2272-2279.

7. Akbal F., Camci S., Comparison of electrocoagulation and chemical coagulation for heavy metal removal, Chem.Eng. Technol. 33 (2010) $1655-1664$.

8. Dermentzis K., Christoforidis A., Valsamidou E., Lazaridou A., Kokkinos N., "Removal of hexavalent chromium from industrial wastewater by electro-coagulation with iron electrodes", Global NEST J., 13 (2011) 412-418.

9. Dermentzis K., Marmanis D., Christoforidis A., Moumtzakis A., Photovoltaic electrocoagulation for remediation of chromium plating wastewaters, Desalination Water Treat., 56 (2015) 1413-1418.
10. El-Taweel Y.A., Nassef E.M., Elkheriari I., Sayed D., Removal of $\mathrm{Cr}(\mathrm{VI})$ ions from waste water by electrocoagulation using iron electrodes, Egypt. J. Petrol. 24 (2015) 183-192.

11. Sharma D., Chaoudhari P.K., Prajapati A.K., Removal of chromium (VI) and lead from electroplating effluent using electrocoagulation, Sep. Sci. Technol. 55 (2020) 321-331.

12. Koshla N.K., Venkachalam S. and Sonrasundaram P., Pulsed electrogeneration of bubbles for electroflotation, J. Appl. Electrochem., 21 (1991) 986-990.

13. Cheballah K., Sahmoune A., Messaoudi K., Drouiche N., Lounici H., Simultaneous removal of hexavalent chromium and COD from industrial wastewater by bipolar electrocoagulation, Chem. Eng. Proc. 96 (2015) 94-99.

14. Aygun A., Nas B., Sevimli M.F., Treatment of reactive dye wastewater by electrocoagulation process: Optimization of costestimation, Korean J. Chem. Eng., 36 (2019) 1441-1449.

15. Dermentzis K., Karakosta K., Kosheleva R., Kokkinos N., Electrochemical remediation of phthalocyanine dye wastewater and simultaneous hydrogen production, J. Eng. Sci. Technol. Review, 13 (2020) 22-25.

16. Deghles A., \& Kurt U., Hydrogen Gas Production from Tannery Wastewater by Electrocoagulation of a Continuous Mode with Simultaneous Pollutants Removal, IOSR J. Appl. Chem., 10 (2017) 40-50. 